\title{
Effects of brewer's spent grain biochar on the growth and quality of leaf lettuce (Lactuca sativa L. var. crispa.)
}

\author{
Jun-Hyuk Yoo ${ }^{1}$, Deogratius Luyima', Jae-Han Lee', Seong-Yong Park' , Jun-Woo Yang ${ }^{1}$, Ji-Young An', \\ Yeo-Uk Yun ${ }^{2^{*}}$ and Taek-Keun Oh ${ }^{1 *}$ (1)
}

\begin{abstract}
The need for organic soil amendments is increasing in the Republic of Korea against the backdrop of increased soil acidification and nutrient losses. The pyrolysis of biomass produces biochar which not only increases soil productivity but also provides environmental benefits through carbon sequestration. The portion of the brewer's spent grain (BSG) recycled is by far less than the amount generated, but pyrolysis can help to reverse this trend by turning BSG waste into a valuable soil amendment. The current study, therefore, evaluated the effects of brewer's spent grain biochar $\left(\mathrm{BB}_{\mathrm{xxx}}\right)$ produced at three different temperatures of $300^{\circ} \mathrm{C}, 500^{\circ} \mathrm{C}$ and $700{ }^{\circ} \mathrm{C}$ on the yield and quality characteristics of the leaf lettuce as well as the effects on soil chemical properties through a pot experiment. Each of the $\mathrm{BB}_{\mathrm{x} x \mathrm{x}}$ and BSG were added to the soil at two rates of $2 \%$ and $5 \%$ by weight. The $\mathrm{pH}$ and carbon content of the BBxxx increased with increasing pyrolysis temperatures and the trend was replicated in the soil upon biochar application i.e. the soil $\mathrm{pH}$ and carbon content increased alongside temperatures at which biochar was pyrolyzed. On the other hand, however, the soil electrical conductivity (EC) diminished with the increasing pyrolysis temperatures of the biochar applied. With regards to crop growth, the $\mathrm{BB}_{500} 5 \%$ amendment produced the highest marketable yield of the leaf lettuce and while the lettuce grown on the control produced leaf lettuce with the lowest content of nitrate nitrogen, $\mathrm{BB}_{500} 5 \%$ amendment generally produced the highest quality lettuce. The results indicate that $\mathrm{BB}_{500}$ performed agronomically better than the rest of the amendments and is thus recommended as an effective BSG recycling measure.
\end{abstract}

Keywords: Biochar, Brewer's spent grain, Leaf lettuce, Pyrolysis, Soil amendment

\section{Introduction}

The granite derived soil predominant in the Republic of Korea has high silicic acid and low cation contents which render it impervious and thus susceptible to erosion from the surfeit of rainfall received which by far exceeds the evaporation rates, culminating into nutrient losses and soil acidification [1]. Soil acidification is further exacerbated directly or indirectly by excessive reactive nitrogen

\footnotetext{
*Correspondence: aoggi61@korea.kr; ok5382@cnu.ac.kr

${ }^{1}$ Department of Bio-Environmental Chemistry, College of Agricultural and Life Sciences, Chungnam National University, Daejeon 34134, Republic of Korea

${ }^{2}$ Division of Environmentally Friendly Agriculture, Chungcheongnam-Do Agricultural Research and Extension Services, Yesan-gun 32418, Korea
}

in the Republic of Korea atmosphere ensuing from automobiles, power plants, chemical fertilizers, etc. the concentration of which is the highest amongst the OECD countries (1.3 times more than the OECD average) [1,2]. There is thus an increasing need to improve the physical, chemical and biological properties of the soil, and biochar is touted as the right organic soil amendment for this job because of its wide-ranging benefits and is receiving great attention.

Biochar is a solid, carbon-rich product which results from heating biomass under conditions of no or limited supply of oxygen in a process called pyrolysis [3]. A lot of research has been done regarding the importance of biochar as a soil amendment with a majority of them 
reporting improved agricultural productivity attributable to improved soil properties including increasing $\mathrm{pH}$, water retention, ion exchange capacity, and improving the microbial environment [4]. Biochar as a sustainable waste management technique provides environmental benefits because it reduces the volume of organic waste resources such as agricultural by-products [5]. It is also an efficient pollutant adsorbent [6-8] as well as a good greenhouse gas emission countermeasure [9-12]. The latter is largely because biochar applied to the soil semipermanently sequesters carbon $[12,13]$. This is possible due to the stability of biochar, which can exist in the soil for an extended period of time owing to its strong resistance to microbial decomposition [4].

Beer is one of the most popular alcoholic beverages in the world and it ranks first in terms of preference for alcoholic beverages in the Republic of Korea [14]. In the manufacture of beer, malt is removed before the fermentation process, in which case BSG, rich in several useful nutrients and functional substances, such as protein, fat, and fiber is generated. BSG is the most abundant brewing by-product, accounting for about $85 \%$ of the total detritus generated which represents approximately $20 \mathrm{~kg}$ per $100 \mathrm{~L}$ of beer produced [15]. BSG is mainly used as fodder for livestock due to its abundant nutrients, but it's not utilized at the same pace as its generated. In fact, about $40 \%$ of the BSG is dumped into the ocean presaging sea contamination [16]. Therefore, further recycling measures of BSG are required, especially because the London Dumping Convention, which South Korea joined completely banned the ocean dumping of organic wastes since 2012 [17].

Leaf lettuce is an annual herbaceous plant of the family Compositae, mostly used as ssam or salad in Korea [18]. Leaf lettuce accounts for a large proportion of leafy vegetables produced in the greenhouses. Domestic production of leaf lettuce is estimated at 224.6 billion won, which is the second largest of all leafy vegetables grown [19]. Leaf lettuce contains functional substances such as carotenoid, and anthocyanin in red lettuce, vitamins $\mathrm{A}$, $B, C, E$, and a large amount of iron and fiber, which are known for physiological activities such as anti-inflammatory, antioxidant, and calming effect [20]. Previous studies by Jung [21] and Oh et al. [5] have reported increased EC upon biochar addition to the soil, and since leaf lettuce is one of the crops relatively sensitive to salt abundancy [22], it is the suitable crop to assess whether biochar induced EC increments cause salt stress to plants.

Therefore, this study was conducted to examine pyrolysis as a way of recycling BSG, delineating the effect of pyrolysis temperatures on the physicochemical properties of the biochar produced. The study also aimed to evaluate the effects of $\mathrm{BB}_{\mathrm{XXX}}$ on the growth and quality of leaf lettuce, and chemical properties of the soil.

\section{Materials and methods Soil preparation and analysis}

The soil used in the experiment was dried at $105{ }^{\circ} \mathrm{C}$ for $24 \mathrm{~h}$ and then strained through a $2 \mathrm{~mm}$ sieve. Soil texture was classified following the U.S. Department of Agriculture (USDA) soil taxonomy after analysis with the hydrometer. Soil $\mathrm{pH}$ and electrical conductivity (EC) were measured by an Electrochemical meter (Orion Versa Star Pro, Thermo Fisher Scientific, USA) after extraction of 1 part of soil with 5 parts of ultrapure water $(\mathrm{w} / \mathrm{v})$ and shaking for $30 \mathrm{~min}$ at $160 \mathrm{rpm}$ on the Orbital Shaker (SH30 Orbital Shaker, Fine PCR, Korea). The contents of carbon $(\mathrm{C})$ and nitrogen $(\mathrm{N})$ were measured by Automatic Elemental Analyzers (Flash 1112 series EA, Thermo Fisher Scientific, USA) while the available phosphorus (Av. $\mathrm{P}_{2} \mathrm{O}_{5}$ ) was extracted with Mehlich No. 3 solution and determined colorimetrically with UVVis Spectrophotometer (Genesys 10S UV-Vis Spectrophotometer, Thermo Fisher Scientific, USA) at $880 \mathrm{~nm}$. Exchangeable cations were assessed with an Inductively Coupled Plasma (iCAP 7000 Series ICP-OES, Thermo Fisher Scientific, USA) after extraction with a $1 \mathrm{~N}$ neutral ammonium acetate solution.

\section{Biochar production and analysis}

BSG was obtained from a local brewing company situated in Jeongnim-dong, Daejeon called The Ranch Brewing co. and was dried for $24 \mathrm{~h}$ in Forced Convection Oven (ON-12Gw L080125, Jeio Tech, Korea) at $85{ }^{\circ} \mathrm{C}$. Dried BSG was then pyrolyzed for $2 \mathrm{~h}$ in a Box furnace $\left(1100{ }^{\circ} \mathrm{C}\right.$ Box Furnace BF51800 Series, Thermo Fisher Scientific, USA) with the internal temperatures set at $300{ }^{\circ} \mathrm{C}, 500{ }^{\circ} \mathrm{C}$ and $700{ }^{\circ} \mathrm{C}$. Photographs of BSG and each of the biochar and their scanning electron microscopy (SEM) images are shown in Fig. 1, biochar is symbolized as $\mathrm{BB}_{\mathrm{XxX}}$ with subscripts referring to corresponding pyrolysis temperatures. The $\mathrm{pH}, \mathrm{EC}, \mathrm{C}$ and $\mathrm{N}$ of $\mathrm{BB}_{\mathrm{Xxx}}$ were measured in the same way as the soil samples but in the case of $\mathrm{pH}$ and $\mathrm{EC}$, the mixing ratio of biochar and ultrapure water was $1: 10(\mathrm{w} / \mathrm{w})$. The available $\mathrm{P}_{2} \mathrm{O}_{5}$ was determined colorimetrically at $470 \mathrm{~nm}$ after extraction with $2 \%$ formic acid. Inorganic contents were measured using ICP-OES (iCAP 7000 Series ICP-OES, Thermo Fisher Scientific, USA) after ashing with the nitric, perchloric and sulfuric acids mixed in ratios of 10:4:1 on a large digital hotplate (HPLP-C-P, Daihan Scientific, Korea) set at $200{ }^{\circ} \mathrm{C}$ followed by dilution $(100,000$ times) with ultrapure water. 


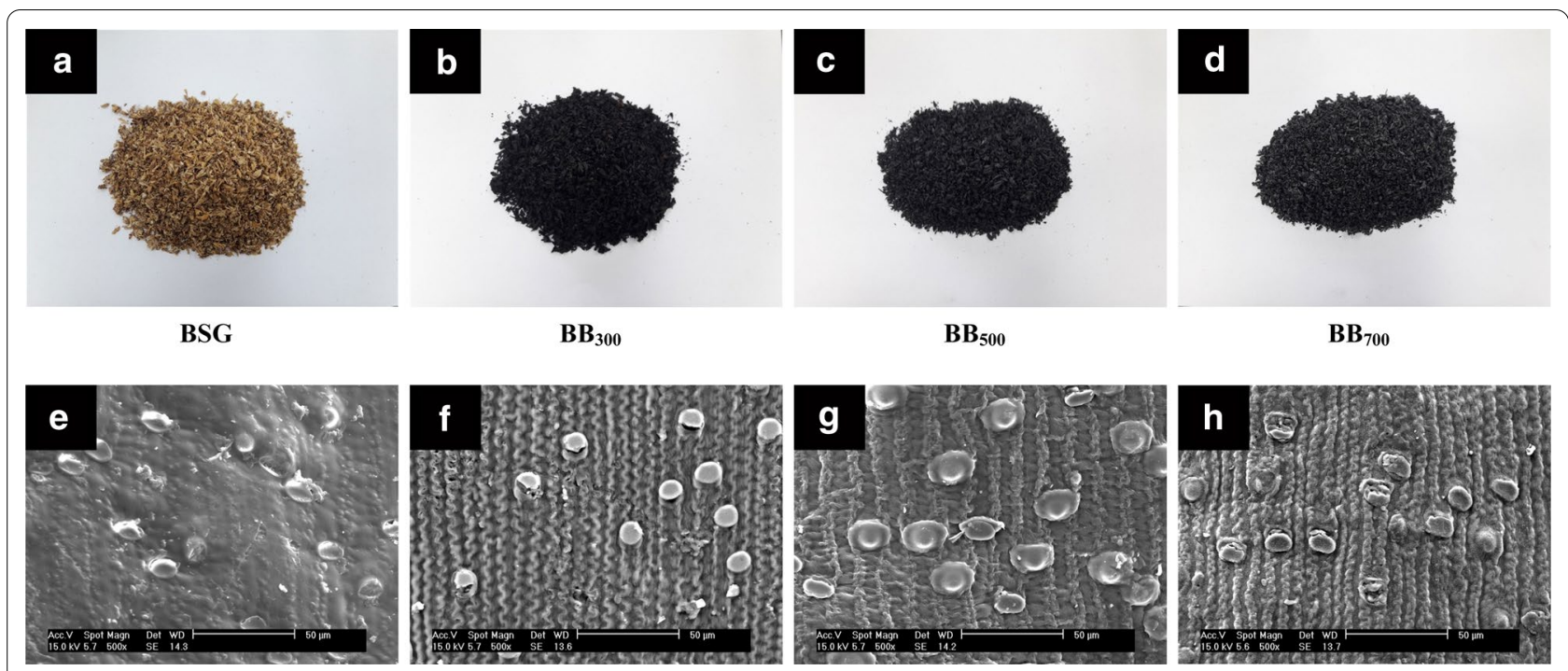

Fig. 1 Photographs of the brewer's spent grain and each of the biochars produced (a-d) and scanning electron microscope (SEM) images of $\mathbf{e}$ brewer's spent grain (BSG), f biochar produced at $300{ }^{\circ} \mathrm{C}\left(\mathrm{BB}_{300}\right), \mathbf{g}$ biochar produced at $500{ }^{\circ} \mathrm{C}\left(\mathrm{BB}_{500}\right)$ and $\mathbf{h}$ biochar produced at $700{ }^{\circ} \mathrm{C}\left(\mathrm{BB}_{700}\right)$

\section{Growth conditions of leaf lettuce}

To evaluate the impact of $\mathrm{BB}_{\mathrm{Xxx}}$ pyrolyzed at varying temperatures on the growth and quality of leaf lettuce, a pot experiment lasting for 35 days was conducted from March 27, 2019 to May 02, 2019 in a greenhouse at Chungnam National University, College of Agriculture and Life Sciences using a 1/5000 (a) Wagner pot. The Lactuca sativa L. var. crispa (cv. 'Jeockchima', Danong Co., Korea) was used in the pot experiment. Seeds were planted in a plug tray, transplanted to the Wagner pots 30 days later and growing them for another 35 days. All biochars and BSG were added to the soil at rates of $2 \%$ and $5 \%(\mathrm{w} / \mathrm{w})$ while the control received neither of the two amendments. The essential elements of N, P and K were supplied at rates recommended by the Rural Development Administration of the republic of Korea. After transplanting, each pot was watered with $200 \mathrm{ml}$ once a day and each of the treatment was replicated thrice.

\section{Assessment of growth and quality of leaf lettuce}

The yield and quality parameters of the leaf lettuce were assessed by paying strict adherence to the Standards for Research and Analysis of Agricultural Science and Technology of the Rural Development Administration [24]. The yield parameters assessed included both the fresh and dry weights of the shoot and the root, the number of leaves per plant, leaf length and width, and the average weight of the leaves while the quality assessments involved measuring sweetness, nitrate-nitrogen $\left(\mathrm{NO}_{3}-\mathrm{N}\right)$, chlorophyll, and anthocyanin. All the assessments were conducted immediately after harvesting for the optimized accuracy of the measurements. Fresh weight was measured after removing moisture remaining on the leaf lettuce, and dry weight was measured after drying the lettuce at $60{ }^{\circ} \mathrm{C}$ for $24 \mathrm{~h}$ in a Forced Convection Oven (ON-12Gw L080125, Jiio Tech, Korea). The average weight of the leaves was computed as the average value of the weight of five heaviest leaves on the plant and the number of leaves index included only leaves that had lengths of $5 \mathrm{~cm}$ and above. Sweetness and $\mathrm{NO}_{3}-\mathrm{N}$ were measured with Digital Saccharimeter (HI 96801, Hanna Instruments Inc, USA) and $\mathrm{NO}_{3}{ }^{-}$-N meter (S040, HORIBA Ltd., Japan), respectively after juice extraction out of the leaves. Chlorophyll content was measured from the mid leaves using chlorophyll meter (SPAD-502, Konica Minolta, Japan) between 10 and 11 a.m. on the harvesting day. The anthocyanin content was measured by taking a $2 \mathrm{~g}$ piece of the leaf lettuce from the second leaf node crushing it in a mortar containing $2 \mathrm{ml}$ of extracting solution made by mixing $95 \%$ ethanol and $1.5 \mathrm{~N} \mathrm{HCl}$ in a ratio of 85:15 (v/v). $1 \mathrm{ml}$ of the supernatant was siphoned off in a micro test tube and stored in a refrigerator set at $4{ }^{\circ} \mathrm{C}$ for $24 \mathrm{~h}$. The supernatant obtained was centrifuged for $20 \mathrm{~min}$ at 13,000 rpm and later diluted with the extracting solution. The anthocyanin content was then analyzed with UV-Vis Spectrophotometer (Genesys $10 \mathrm{~s}$ UV-Vis, Thermo Fisher Scientific, USA) set at $535 \mathrm{~nm}$ (Fuleki and Francis 1968).

\section{Statistical analysis}

Statistical analysis of the data obtained was conducted by a one-way analysis of variance (ANOVA) of the SPSS 


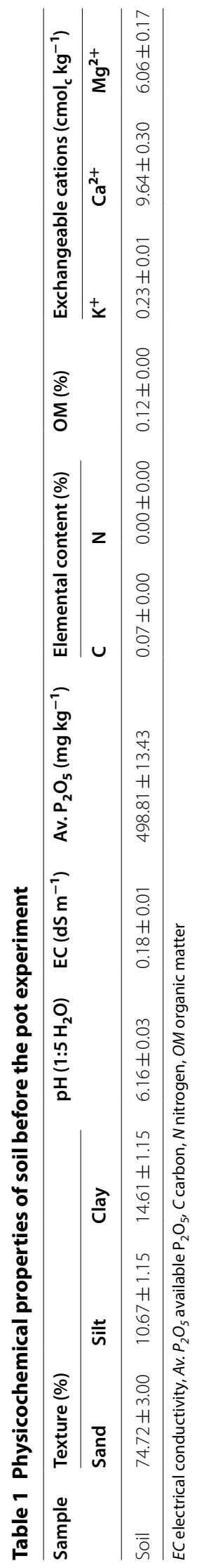


(IBM SPSS Statistics version 24.0) for significance and post-testing was performed through Duncan method, variability in the data was expressed as the standard deviation, and a value of $P<0.05$ was considered to be statistically significant.

\section{Results}

\section{Physicochemical properties of soil, $B S G$, and $\mathrm{BB}_{\mathrm{xxx}}$}

The results of the physicochemical properties of the soil before leaf lettuce cultivation are shown in Table 1. The ratio of sand, silt, and clay in the soil was 74.72, 10.67 and $14.61 \%$, respectively, therefore, the soil texture was adjudged as sandy loam following the USDA soil taxonomy. The soil was weakly acidic with a $\mathrm{pH}$ of 6.16 , the EC was $0.18\left(\mathrm{dS} \mathrm{m}^{-1}\right)$ while the available $\mathrm{P}_{2} \mathrm{O}_{5}$ was 498.81 $\left(\mathrm{mg} \mathrm{kg}^{-1}\right)$. C content was $0.07 \%$ but $\mathrm{N}$ was not detected. Exchangeable cations amounted to $0.23,9.64$ and 6.06 $\left(\mathrm{cmol}_{\mathrm{c}} \mathrm{kg}^{-1}\right)$ of $\mathrm{K}^{+}, \mathrm{Ca}^{2+}$ and $\mathrm{Mg}^{2+}$, respectively.

As indicated in Table 2, biochar yield decreased with the increasing pyrolysis temperatures with the yield amounting to $52.40,27.30$ and $24.19 \%$ of the BSG biomass when pyrolyzed at 300,500 and $700{ }^{\circ} \mathrm{C}$, respectively. On the other hand, $\mathrm{pH}$ of the biochar $\mathrm{BB}_{300}$, $\mathrm{BB}_{500}$ and $\mathrm{BB}_{700}$ increased to 6.02, 7.10 and 7.82, respectively from 5.20 in BSG. EC of the biochar in the current study decreased from 2.69 in BSG to $0.73,0.41$ and $0.21\left(\mathrm{dS} \mathrm{m}^{-1}\right)$ at 300,500 and $700{ }^{\circ} \mathrm{C}$, respectively. The $\mathrm{T}-\mathrm{P}$ contents were in the order of $\mathrm{BB}_{500}(3.75 \%)>\mathrm{BB}_{700}$ $(3.39 \%)>\mathrm{BB}_{300} \quad(1.57 \%)>\mathrm{BSG} \quad(1.01 \%) . \quad \mathrm{C}$ and $\mathrm{C} / \mathrm{N}$ increased with the increasing pyrolysis temperatures while the $\mathrm{N}$ content was highest in the $\mathrm{BB}_{500}(4.87 \%)$ followed by $\mathrm{BB}_{300}(4.47 \%)$, BSG (3.96\%) and $\mathrm{BB}_{700}(3.79 \%)$. Inorganic contents of $\mathrm{K}_{2} \mathrm{O}, \mathrm{CaO}$ and $\mathrm{MgO}$ were highest in the $\mathrm{BB}_{500}$ with concentrations standing at $0.24,1.26$ and $1.35 \%$, respectively.

\section{Chemical properties of the soil after leaf lettuce growth}

The results of the chemical properties of the soil after the growth of the leaf lettuce on $\mathrm{BSG}$ and $\mathrm{BB}_{\mathrm{XxX}}$ amended soils are shown in Table 3. While the $\mathrm{pH}$ of the control experiment declined to 6.06, those of BSG and $\mathrm{BB}_{\mathrm{Xxx}}$ amended soils increased although the increments were higher in the $5 \%$ than in the $2 \%$ amended soils except for BSG treatment. The application of BSG to the soil augmented its $\mathrm{EC}$ while $\mathrm{BB}_{\mathrm{Xxx}}$ amendments produced opposite effects on the soil reflecting their corresponding low EC values. In addition, the EC values were higher in soils amended with $\mathrm{BB}_{\mathrm{Xxx}} 5 \%$ than those with $2 \%$ for all the treatments.

The available $\mathrm{P}_{2} \mathrm{O}_{5}$ increased in all the $\mathrm{BB}_{\mathrm{XxX}}$ amended soils compared with the control but $\mathrm{BB}_{300} 5 \%$ registered a value less than that of the control. Soil $\mathrm{C}$ content increased in all the $\mathrm{BB}_{\mathrm{Xxx}}$ amended soils and the increments were magnified with the application of biochar pyrolyzed at higher temperatures and at a higher application rate of $5 \%$. Consequently, the amount of organic matter in the soil also increased in the same fashion with a maximum value of $6.35 \%$ obtained with the application of $\mathrm{BB}_{700}$ at $5 \%$. The soil $\mathrm{N}$ content in the control was not detected as was the case at the beginning of the experiment while its concentration was higher in the $2 \%$ than in the $5 \%$ BSG and $\mathrm{BB}_{\mathrm{Xxx}}$ treatments, with a maximum value of $0.20 \%$ recorded in $\mathrm{BB}_{500} 5 \%$ and $\mathrm{BB}_{700} 5 \%$ amendments. The highest values for the exchangeable cations were $0.24,9.44$ and $6.21\left(\mathrm{cmol}_{\mathrm{c}} \mathrm{kg}^{-1}\right)$ for $\mathrm{K}^{+}$in BSG $5 \%, \mathrm{Ca}^{2+}$ in $\mathrm{BB}_{500} 2 \%$ and $\mathrm{Mg}^{2+}$ in $\mathrm{BB}_{300} 2 \%$ amendments, respectively.

\section{Growth characteristics of leaf lettuce}

Photographs of leaf lettuce grown on each BSG and $\mathrm{BB}_{\mathrm{XXX}}$ amended soils are shown in Fig. 2 while their growth characteristics are indicated in Table 4 . The $\mathrm{BB}_{500}$ $5 \%$ treatment produced the most stunning results across all the growth characteristics measured except for the number of leaves. In that regard, $\mathrm{BB}_{500} 5 \%$ treatment outperformed the rest of the amendments and was closely followed by $\mathrm{BB}_{500} 2 \%$ treatment while BSG $5 \%$ treatment elicited adverse effects on leaf lettuce growth. Typically, the fresh shoot weight of the lettuce (107.24 g plant ${ }^{-1}$ ) produced from a $\mathrm{BB}_{500} 5 \%$ amended soil was approximately 1.44 times higher than that of the control (74.29 $\left.\mathrm{g} \mathrm{plant}^{-1}\right)$, whereas the fresh shoot weight of the BSG 5\% treatment (32.78 $\mathrm{g} \mathrm{plant}^{-1}$ ) was approximately 0.44 times lower than the control. It is thus evident that $\mathrm{BB}_{\mathrm{XxX}}$ amendments were largely beneficial while the pristine BSG amendment was mainly detrimental. Also, higher application rates of $\mathrm{BB}_{\mathrm{XxX}}(5 \%)$ led to lower lettuce yields than the $2 \%$ amendment except for $\mathrm{BB}_{500}$ amendment as shown in Table 3.

The fresh roots of $\mathrm{BB}_{500}$ and $\mathrm{BB}_{700}$ treatments were heavier than the control. The heaviest fresh roots of $76.04 \mathrm{~g}$ were obtained from $\mathrm{BB}_{500} 5 \%$ amendment, a value approximately 1.67 times higher than the fresh root weight of the control $(45.60 \mathrm{~g})$ while the fresh root weight of the BSG 5\% treatment (15.56 g) was about 2.9 times lower than that of the control. The average water content of the plant shoots of all the treatments was recorded at about $92 \%$ with no significant differences amongst the treatments while the average value of water content in the plant roots stood at approximately $86 \%$ with no significant differences among the treatments. 
Table 2 Physicochemical properties of dried BSG, and BBxxx produced at the different pyrolysis temperatures

\begin{tabular}{|c|c|c|c|c|c|c|c|c|c|c|}
\hline \multirow[t]{2}{*}{ Sample } & \multirow[t]{2}{*}{ Yield (\%) } & \multirow[t]{2}{*}{$\mathrm{pH}\left(1: 10 \mathrm{H}_{2} \mathrm{O}\right)$} & \multirow[t]{2}{*}{$E C\left(d S m^{-1}\right)$} & \multirow[t]{2}{*}{ T-P (\%) } & \multicolumn{2}{|c|}{ Elemental content (\%) } & \multirow[t]{2}{*}{$\mathrm{C} / \mathrm{N}$ ratio } & \multicolumn{3}{|c|}{ Inorganic contents (\%) } \\
\hline & & & & & $\mathrm{C}$ & $\mathrm{N}$ & & $\mathrm{K}_{2} \mathrm{O}$ & $\mathrm{CaO}$ & $\mathrm{MgO}$ \\
\hline BSG & - & $5.20 \pm 0.01$ & $2.69 \pm 0.01$ & $1.01 \pm 0.01$ & $51.04 \pm 1.37$ & $3.96 \pm 0.20$ & $12.91 \pm 0.33$ & $0.08 \pm 0.01$ & $0.40 \pm 0.01$ & $0.41 \pm 0.01$ \\
\hline $\mathrm{BB}_{300}$ & $52.40 \pm 1.42$ & $6.02 \pm 0.03$ & $0.73 \pm 0.00$ & $1.57 \pm 0.10$ & $66.43 \pm 1.88$ & $4.47 \pm 0.25$ & $14.89 \pm 0.83$ & $0.15 \pm 0.04$ & $0.73 \pm 0.02$ & $0.71 \pm 0.03$ \\
\hline $\mathrm{BB}_{500}$ & $27.30 \pm 0.73$ & $7.10 \pm 0.00$ & $0.41 \pm 0.00$ & $3.75 \pm 0.14$ & $73.40 \pm 1.64$ & $4.87 \pm 0.14$ & $15.06 \pm 0.46$ & $0.24 \pm 0.01$ & $1.26 \pm 0.02$ & $1.35 \pm 0.02$ \\
\hline $\mathrm{BB}_{700}$ & $24.19 \pm 1.41$ & $7.82 \pm 0.03$ & $0.21 \pm 0.00$ & $3.39 \pm 0.08$ & $76.07 \pm 1.74$ & $3.79 \pm 0.05$ & $20.09 \pm 0.40$ & $0.22 \pm 0.00$ & $1.18 \pm 0.04$ & $1.35 \pm 0.02$ \\
\hline
\end{tabular}

$B S G$ brewer's spent grain, $B B x x x$ brewer's spent grain biochar (pyrolyzed at $x x x^{\circ} \mathrm{C}$ ), $E C$ electrical conductivity, $T-P$ total phosphorus, $C$ carbon, $N$ nitrogen, $O M$ organic matter

Table 3 Chemical properties of the soils under the different amendments at the end of the leaf lettuce growing season

\begin{tabular}{|c|c|c|c|c|c|c|c|c|c|}
\hline \multirow[t]{2}{*}{ Treatment } & \multirow[t]{2}{*}{$\mathrm{pH}\left(1: 5 \mathrm{H}_{2} \mathrm{O}\right)$} & \multirow[t]{2}{*}{$\mathrm{EC}\left(\mathrm{dS} \mathrm{m^{-1 } )}\right.$} & \multirow[t]{2}{*}{ Av. $\mathrm{P}_{2} \mathrm{O}_{5}\left(\mathrm{mg} \mathrm{kg}^{-1}\right)$} & \multicolumn{2}{|c|}{ Element content (\%) } & \multirow[t]{2}{*}{ OM (\%) } & \multicolumn{3}{|c|}{ Exchangeable cations $\left(\mathrm{cmol}_{\mathbf{c}} \mathbf{~ k g}^{-1}\right)$} \\
\hline & & & & C & $\mathbf{N}$ & & $\overline{\mathrm{K}^{+}}$ & $\mathrm{Ca}^{2+}$ & $\mathrm{Mg}^{2+}$ \\
\hline Control & $6.06 \pm 0.02^{c}$ & $0.26 \pm 0.00^{b c}$ & $532.2 \pm 19.4^{f}$ & $6 \pm 0.01^{c}$ & $0.00 \pm 0.00^{c}$ & $0.10 \pm 0.01^{d}$ & $0.15 \pm 0.01^{b}$ & $8.40 \pm 0.20^{c}$ & $5.21 \pm 0.13^{c}$ \\
\hline BSG $2 \%$ & $6.53 \pm 0.16^{\mathrm{a}}$ & $0.37 \pm 0.07^{b}$ & $876.2 \pm 24.1^{c}$ & $0.34 \pm 0.01^{c}$ & $0.04 \pm 0.01^{c}$ & $0.59 \pm 0.02^{d}$ & $0.18 \pm 0.04^{\mathrm{ab}}$ & $8.94 \pm 0.63^{a b c}$ & $5.79 \pm 0.41^{b}$ \\
\hline BSG 5\% & $6.35 \pm 0.08^{b}$ & $1.12 \pm 0.21^{\mathrm{a}}$ & $603.6 \pm 14.2^{d}$ & $0.66 \pm 0.38^{c}$ & $0.09 \pm 0.06^{b}$ & $1.13 \pm 0.66^{d}$ & $0.24 \pm 0.02^{\mathrm{a}}$ & $8.68 \pm 0.35^{b c}$ & $5.77 \pm 0.21^{b}$ \\
\hline $\mathrm{BB}_{300} 2 \%$ & $6.29 \pm 0.06^{b}$ & $0.22 \pm 0.02^{b c}$ & $580.3 \pm 13.3^{e}$ & $0.61 \pm 0.10^{c}$ & $0.04 \pm 0.01^{c}$ & $1.06 \pm 0.17^{d}$ & $0.14 \pm 0.01^{b}$ & $9.42 \pm 0.38^{\mathrm{a}}$ & $6.21 \pm 0.27^{\mathrm{a}}$ \\
\hline $\mathrm{BB}_{300} 5 \%$ & $6.38 \pm 0.11^{\mathrm{ab}}$ & $0.26 \pm 0.03^{b c}$ & $452.0 \pm 11.4^{9}$ & $1.40 \pm 0.07^{b}$ & $0.10 \pm 0.01^{b}$ & $2.41 \pm 0.12^{c}$ & $0.18 \pm 0.04^{a b}$ & $9.01 \pm 0.07^{\mathrm{ab}}$ & $6.14 \pm 0.09^{\mathrm{ab}}$ \\
\hline $\mathrm{BB}_{500} 2 \%$ & $6.30 \pm 0.07^{b}$ & $0.21 \pm 0.00^{c}$ & $890.5 \pm 15.2^{b}$ & $1.67 \pm 0.23^{b}$ & $0.12 \pm 0.02^{b}$ & $2.88 \pm 0.40^{c}$ & $0.20 \pm 0.09^{a b}$ & $9.44 \pm 0.07^{\mathrm{a}}$ & $6.13 \pm 0.11^{\mathrm{ab}}$ \\
\hline $\mathrm{BB}_{500} 5 \%$ & $6.41 \pm 0.07^{\mathrm{ab}}$ & $0.24 \pm 0.01^{b c}$ & $907.3 \pm 17.4^{\mathrm{a}}$ & $2.96 \pm 0.77^{b}$ & $0.20 \pm 0.06^{\mathrm{a}}$ & $5.10 \pm 1.33^{b}$ & $0.18 \pm 0.03^{\mathrm{ab}}$ & $8.94 \pm 0.19^{a b c}$ & $6.14 \pm 0.12^{\mathrm{ab}}$ \\
\hline $\mathrm{BB}_{700} 2 \%$ & $6.32 \pm 0.09^{b}$ & $0.19 \pm 0.01^{c}$ & $573.4 \pm 18.4^{\mathrm{e}}$ & $1.82 \pm 0.32^{b}$ & $0.10 \pm 0.03^{b}$ & $3.13 \pm 0.56^{c}$ & $0.17 \pm 0.02^{\mathrm{ab}}$ & $9.15 \pm 0.21^{\mathrm{ab}}$ & $6.11 \pm 0.09^{\mathrm{ab}}$ \\
\hline $\mathrm{BB}_{700} 5 \%$ & $6.42 \pm 0.02^{\mathrm{ab}}$ & $0.25 \pm 0.01^{b c}$ & $566.1 \pm 9.8^{e}$ & $3.68 \pm 0.36^{\mathrm{a}}$ & $0.20 \pm 0.03^{\mathrm{a}}$ & $6.35 \pm 0.63^{\mathrm{a}}$ & $0.18 \pm 0.01^{\mathrm{ab}}$ & $8.96 \pm 0.25^{\mathrm{abc}}$ & $5.74 \pm 0.23^{b}$ \\
\hline
\end{tabular}

The letters denote significant differences amongst the different treatments based on the results of the Tukey posthoc tests

$B S G$ brewer's spent grain, $B B x x x$ brewer's spent grain biochar (pyrolyzed at xxx ${ }^{\circ} \mathrm{C}$ ), EC electrical conductivity, $A v \cdot P_{2} \mathrm{O}_{5}$ available $\mathrm{P}_{2} \mathrm{O}_{5}, C$ carbon, $N$ nitrogen, $O M$ organic matter

\section{Quality characteristics of leaf lettuce}

The quality characteristics of leaf lettuce grown on BSG and BBxxx amended soils are shown in Table 5. Sweetness degree of the leaf lettuce was highest in the crops grown on the $\mathrm{BB}_{700} 5 \%$ amendment (3.83 Brix) whereas the lowest value of 1.67 (Brix) came from the $\mathrm{BB}_{300} 5 \%$ amendment. The nitrate-nitrogen content was generally high in lettuce grown on $\mathrm{BB}_{500}$ and $\mathrm{BB}_{700}$ amended soils, with the highest value of $2200\left(\mathrm{mg} \mathrm{kg}^{-1}\right)$ obtained from $\mathrm{BB}_{500} 2 \%$ treatment while the lowest nitrate-nitrogen content was recorded in the control $\left(773.33 \mathrm{mg} \mathrm{kg}^{-1}\right)$. Chlorophyll content was highest in the lettuce grown on $\mathrm{BB}_{500} 2 \%$ treatment (33.73 SPAD) and lowest in the crops grown on the $\mathrm{BB}_{700} 5 \%$ treatment (25.47 SPAD). The anthocyanin content was highest with the $\mathrm{BB}_{700}$ $2 \%$ treatment $\left(0.28 \mathrm{mg} \mathrm{g}^{-1}\right)$ and lowest in the BSG $5 \%$ $\left(0.15 \mathrm{mg} \mathrm{g}^{-1}\right)$.

\section{Discussion}

As indicated above, the yield of biochar decreased with increasing pyrolysis temperatures which accorded with the observations made by Woo [4] and Lim et al. [25] that the higher the pyrolysis temperature of biomass, the lower the biochar yield. The $\mathrm{pH}$ of the biochar $\mathrm{BB}_{300}$, $\mathrm{BB}_{500}$ and $\mathrm{BB}_{700}$ rose with increasing pyrolysis temperature. The concentration of alkaline salts increased along pyrolysis temperatures, an observation consistent with the previous studies by Ahmed et al. [26], Shinogi and Kanri [27] and Oh et al. [28]. EC of $\mathrm{BB}_{\mathrm{XxX}}$ decreased with the increasing pyrolysis temperatures contrary to most previously conducted studies by Cantrell et al. [29], Lim et al. $[25,30]$ who reported increased EC upon increasing the pyrolysis temperatures. Mussatto et al. [15] reported that the hot water extraction drains a lot of components out of the malt while Lee et al. [16] indicated that due to the extraction of beer components, brewer's spent grain contains lower ash content than other biomass which may explain the decreasing trend of EC values observed. Additionally, Woo [4] revealed that the ratio of stable aromatic hydrocarbons increases as the pyrolysis temperature of the biochar increases. Hence, since the hot water extraction of malt during the beer production process had already extracted a lot of components, producing lignin-rich brewer's spent grain, pyrolysis of BSG increases the aromatic hydrocarbons, stabilizing the biochar and lowering the $\mathrm{EC}$ of the resultant $\mathrm{BB}_{\mathrm{XXX}}$. The 


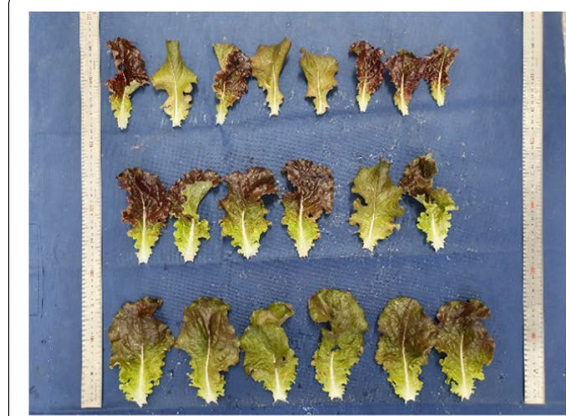

Control

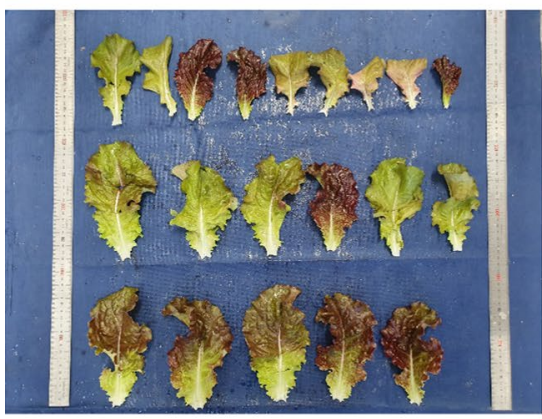

$\mathrm{BB}_{300} 2 \%$

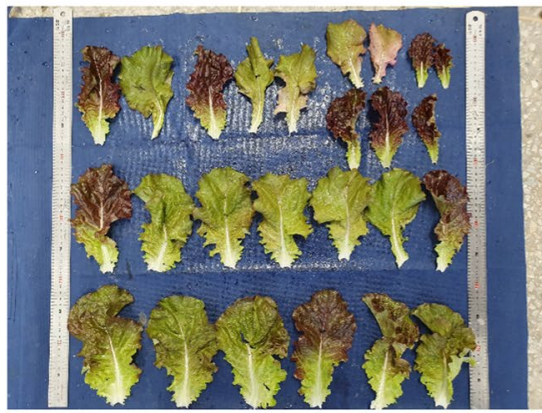

$\mathrm{BB}_{500} 5 \%$

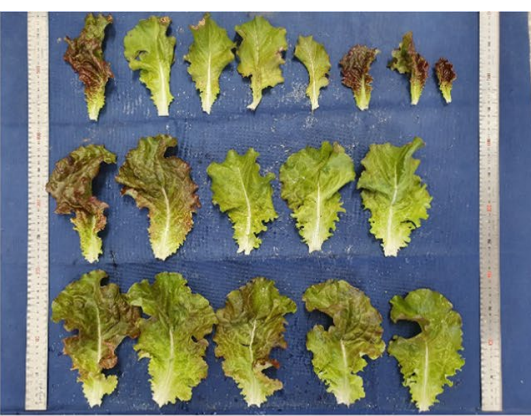

BSG 2\%

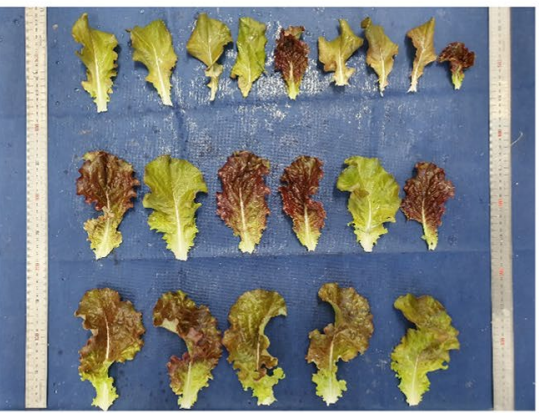

$\mathrm{BB}_{300} 5 \%$

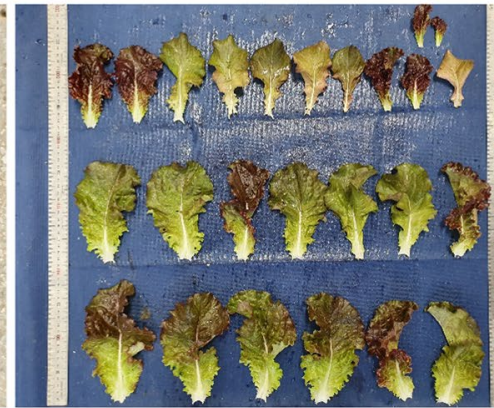

$\mathrm{BB}_{700} 2 \%$

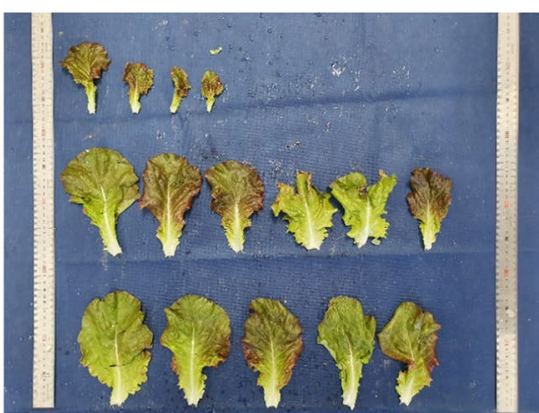

BSG 5\%

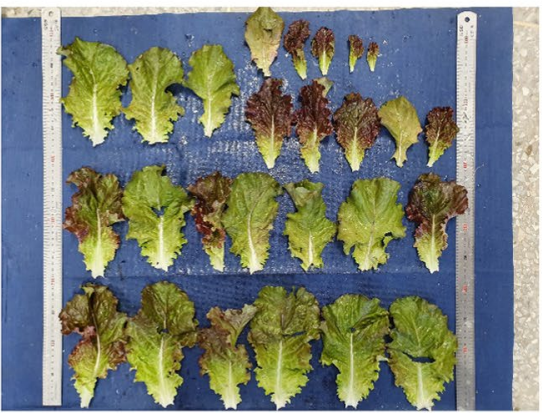

$\mathrm{BB}_{500} 2 \%$

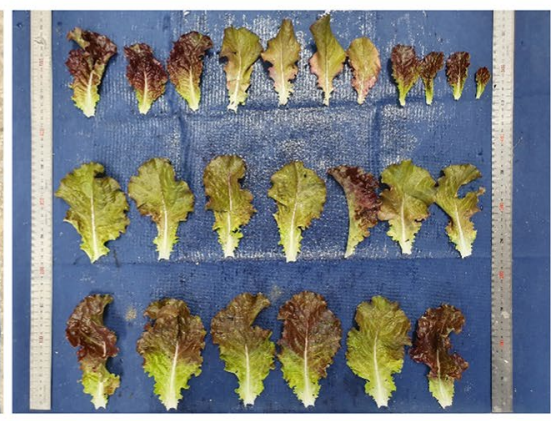

$\mathrm{BB}_{700} 5 \%$

Fig. 2 Photographs of the leaf lettuce leaves obtained

Table 4 Yield components of the leaf lettuce

\begin{tabular}{|c|c|c|c|c|c|c|c|c|}
\hline Treatment & $\begin{array}{l}\text { Fresh shoot (g } \\
\text { plant }^{-1} \text { ) }\end{array}$ & $\begin{array}{l}\text { Fresh root (g } \\
\text { plant }^{-1} \text { ) }\end{array}$ & $\begin{array}{l}\text { Dry shoot (g } \\
\text { plant }^{-1} \text { ) }\end{array}$ & $\begin{array}{l}\text { Dry root (g } \\
\left.\text { plant }^{-1}\right)\end{array}$ & $\begin{array}{l}\text { Number } \\
\text { of leaves (ea } \\
\text { plant }^{-1} \text { ) }\end{array}$ & $\begin{array}{l}\text { Leaf length } \\
\text { (cm) }\end{array}$ & $\begin{array}{l}\text { Leaf width } \\
\text { (cm) }\end{array}$ & $\begin{array}{l}\text { Weight } \\
\text { per leaf (g } \\
\text { plant }^{-1} \text { ) }\end{array}$ \\
\hline ontrol & $74.29 \pm 2.99^{b}$ & $45.60 \pm 3.50^{b c}$ & $6.79 \pm 1.12^{b c}$ & $8.07 \pm 0.23^{b c d}$ & $19.00 \pm 1.00^{\mathrm{bcd}}$ & $16.01 \pm 0.19^{b c}$ & $10.05 \pm 0.48^{\mathrm{abc}}$ & $24.61 \pm 2.50^{a b}$ \\
\hline BSG 2\% & $67.05 \pm 19.25^{b c}$ & $26.19 \pm 2.66^{\mathrm{de}}$ & $6.18 \pm 2.21^{c}$ & $4.36 \pm 0.49^{e f}$ & $15.67 \pm 2.08^{\mathrm{de}}$ & $14.88 \pm 2.27^{\mathrm{cd}}$ & $12.41 \pm 2.86^{\mathrm{a}}$ & $28.58 \pm 10.68^{a}$ \\
\hline BSG 5\% & $32.78 \pm 7.74^{d}$ & $15.56 \pm 4.48^{e}$ & $2.92 \pm 0.90^{d}$ & $2.67 \pm 0.53^{f}$ & $12.33 \pm 2.52^{e}$ & $12.88 \pm 2.54^{\mathrm{d}}$ & $8.37 \pm 2.28^{c}$ & $14.33 \pm 2.81^{c}$ \\
\hline $\mathrm{BB}_{300} 2 \%$ & $79.82 \pm 9.17^{b}$ & $39.18 \pm 9.20^{b c}$ & $6.48 \pm 0.89^{c}$ & $5.93 \pm 1.26^{\mathrm{de}}$ & $19.67 \pm 0.58^{\mathrm{bcd}}$ & $16.65 \pm 2.28^{b c}$ & $11.79 \pm 0.45^{\mathrm{ab}}$ & $30.46 \pm 3.60^{\mathrm{a}}$ \\
\hline $\mathrm{BB}_{300} 5 \%$ & $53.38 \pm 12.65^{c}$ & $37.44 \pm 9.35^{c d}$ & $5.06 \pm 1.68^{c}$ & $6.25 \pm 1.56^{\text {cde }}$ & $18.00 \pm 2.65^{c d}$ & $15.44 \pm 2.17^{c d}$ & $9.39 \pm 1.61^{b c}$ & $16.86 \pm 4.29^{b c}$ \\
\hline $\mathrm{BB}_{500} 2 \%$ & $106.87 \pm 4.73^{a}$ & $51.41 \pm 8.88^{b}$ & $8.79 \pm 0.99^{\mathrm{ab}}$ & $9.08 \pm 1.89^{b}$ & $24.00 \pm 2.00^{\mathrm{a}}$ & $19.13 \pm 1.31^{\mathrm{ab}}$ & $12.42 \pm 1.12^{\mathrm{a}}$ & $34.34 \pm 6.60^{\mathrm{a}}$ \\
\hline $\mathrm{BB}_{500} 5 \%$ & $107.24 \pm 3.05^{\mathrm{a}}$ & $76.04 \pm 6.42^{\mathrm{a}}$ & $9.31 \pm 0.69^{\mathrm{a}}$ & $11.44 \pm 0.79^{a}$ & $23.00 \pm 2.00^{\mathrm{ab}}$ & $19.72 \pm 0.72^{\mathrm{a}}$ & $12.67 \pm 0.30^{\mathrm{a}}$ & $31.41 \pm 3.71^{\mathrm{a}}$ \\
\hline $\mathrm{BB}_{700} 2 \%$ & $77.07 \pm 7.31^{b}$ & $47.62 \pm 6.88^{b c}$ & $6.20 \pm 0.78^{c}$ & $7.85 \pm 1.10^{\mathrm{bcd}}$ & $23.00 \pm 3.46^{\mathrm{ab}}$ & $16.30 \pm 0.96^{b c}$ & $10.10 \pm 0.69^{a b c}$ & $27.27 \pm 3.23^{\mathrm{a}}$ \\
\hline $\mathrm{BB}_{700} 5 \%$ & $72.97 \pm 0.82^{b}$ & $46.87 \pm 9.06^{b c}$ & $6.99 \pm 0.50^{b c}$ & $8.53 \pm 2.46^{b c}$ & $21.67 \pm 2.08^{\mathrm{abc}}$ & $16.44 \pm 0.37^{b c}$ & $10.60 \pm 0.43^{\mathrm{abc}}$ & $24.99 \pm 0.29^{a b}$ \\
\hline
\end{tabular}

The letters denote significant differences amongst the different treatments based on the results of the Tukey posthoc tests $B S G$ brewer's spent grain, $B B x x x$ brewer's spent grain biochar (pyrolyzed at $x x x^{\circ} \mathrm{C}$ ) 
Table 5 Quality characteristics of leaf lettuce produced with the different amendments

\begin{tabular}{lllll}
\hline Treatment & Sweetness degree (Brix) & Nitrate-nitrogen $\left.\mathbf{( m g ~ k g}^{\mathbf{- 1}}\right)$ & Chlorophyll (SPAD) & Anthocyanin (mg g \\
\hline Control & $3.30 \pm 0.36^{\mathrm{b}}$ & $773.3 \pm 198.6^{\mathrm{d}}$ & $31.03 \pm 1.50^{\mathrm{abc}}$ & $0.25 \pm 0.05^{\mathrm{a}}$ \\
$\mathrm{BSG} 2 \%$ & $2.47 \pm 0.50^{\mathrm{de}}$ & $1236.6 \pm 398.8^{\mathrm{c}}$ & $28.60 \pm 2.23^{\mathrm{bcd}}$ & $0.25 \pm 0.11^{\mathrm{ab}}$ \\
$\mathrm{BSG} 5 \%$ & $3.17 \pm 0.25^{\mathrm{bc}}$ & $1466.6 \pm 152.8^{\mathrm{bc}}$ & $26.33 \pm 1.40^{\mathrm{cd}}$ & $0.15 \pm 0.07^{\mathrm{b}}$ \\
$\mathrm{BB}_{300} 2 \%$ & $2.67 \pm 0.06^{\mathrm{cd}}$ & $1333.3 \pm 321.5^{\mathrm{c}}$ & $27.93 \pm 2.36^{\mathrm{cd}}$ & $0.21 \pm 0.07^{\mathrm{ab}}$ \\
$\mathrm{BB}_{300} 5 \%$ & $1.67 \pm 0.35^{\mathrm{f}}$ & $1073.3 \pm 241.1^{\mathrm{cd}}$ & $28.87 \pm 3.95^{\mathrm{abcd}}$ & $0.26 \pm 0.02^{\mathrm{a}}$ \\
$\mathrm{BB}_{500} 2 \%$ & $2.07 \pm 0.25^{\mathrm{ef}}$ & $2200.0 \pm 264.6^{\mathrm{a}}$ & $33.73 \pm 4.16^{\mathrm{a}}$ & $0.26 \pm 0.00^{\mathrm{a}}$ \\
$\mathrm{BB}_{500} 5 \%$ & $3.00 \pm 0.20^{\mathrm{bcd}}$ & $1466.6 \pm 251.7^{\mathrm{bc}}$ & $33.27 \pm 2.94^{\mathrm{ab}}$ & $0.26 \pm 0.03^{\mathrm{a}}$ \\
$\mathrm{BB}_{700} 2 \%$ & $3.07 \pm 0.23^{\mathrm{bc}}$ & $1866.6 \pm 152.8^{\mathrm{ab}}$ & $29.63 \pm 2.46^{\mathrm{abcd}}$ & $0.28 \pm 0.04^{\mathrm{a}}$ \\
$\mathrm{BB}_{700} 5 \%$ & $3.83 \pm 0.31^{\mathrm{a}}$ & $1466.7 \pm 152.8^{\mathrm{bc}}$ & $25.47 \pm 1.36^{\mathrm{d}}$ & $0.26 \pm 0.03^{\mathrm{a}}$ \\
\hline $\mathrm{T}^{\mathrm{a}}$ & &
\end{tabular}

The letters denote significant differences amongst the different treatments based on the results of the Tukey posthoc tests

$B S G$ brewer's spent grain, BBxxx brewer's spent grain biochar (pyrolyzed at $x x x^{\circ} \mathrm{C}$ )

observed increase in carbon content of the $\mathrm{BB}_{300}, \mathrm{BB}_{500}$ and $\mathrm{BB}_{700}$ with increasing pyrolysis temperature corresponded well to a previous study by Lim et al. [25]. Woo [4] reported that depending on the temperature at which biochar is produced, the higher the pyrolysis temperature, the higher the carbon content and recalcitrance of the resultant biochar.

The changes in soil $\mathrm{pH}$ showed closeness to the intrinsic $\mathrm{pH}$ values of $\mathrm{BB}_{\mathrm{XXX}}$ but $\mathrm{BSG}$ amended soil surprisingly registered a high increase in $\mathrm{pH}$ although BSG had an inherently low $\mathrm{pH}$. The latter could have been due to evolution of ammonia from the decomposition of uncharred organic waste (BSG) as was elaborated by Yang et al. [31]. Available $\mathrm{P}_{2} \mathrm{O}_{5}$ of the amended soils increased with increasing pyrolysis temperatures. The increased available $\mathrm{P}_{2} \mathrm{O}_{5}$ may be due to the rise in $\mathrm{pH}$ of the soil elicited by $\mathrm{BB}_{\mathrm{XXX}}$ amendments. Previous studies by Kim et al. [17] and Kang and Hong [32] reported that the available $\mathrm{P}_{2} \mathrm{O}_{5}$ concentration increased by up to 1.7 times when the soil $\mathrm{pH}$ increased from 4.0 to 8.0 and 3.5 times above $\mathrm{pH}$ 8.0. Additionally, due to the hydrolysis of phosphoric acid compounds and reduction of iron oxides [32], the available $\mathrm{P}_{2} \mathrm{O}_{5}$ is expected to increase. The observed increases in exchangeable cations in all the amended soils were in agreement with previous observations by Lee et al. [33, 34] who observed similar increments in soil exchangeable cation concentrations upon biochar addition to the soil. This result is judged to have been affected by inorganic contents contained in the biochar.

Biochar has recently drawn significant attention from many researchers for its potential as a soil amendment to improve crop growth $[35,36]$. In our current study, the $\mathrm{BB}_{300} 2 \%, \mathrm{BB}_{500} 2 \%, \mathrm{BB}_{500} 5 \%$ and $\mathrm{BB}_{700} 2 \%$ showed higher growth results than the control, an observation that accorded with previously concluded studies by Lee et al. [34] and Luyima et al. [37] who reported improved plant growth upon biochar addition to the soil. The fresh roots of $\mathrm{BB}_{500}$ and $\mathrm{BB}_{700}$ treatments were heavier than the control something that concurred with Chan et al. [38] who delineated that biochar increases the growth of plant roots. Therefore, biochar amendments had positive effects on the growth of crops with the most outstanding result coming from the $\mathrm{BB}_{500}$ amendment. Lee et al. [33] reported that biochar amended soil affects nitrate nitrogen contents in crops. This study showed that biochar improved the absorption of nitrate-nitrogen possibly through aiding proper root growth in the $\mathrm{BB}_{500}$ and $\mathrm{BB}_{700}$ amended soils and was in agreement with a study by $\mathrm{Oh}$ et al. [5] who reported that biochar amendments support proper root growth which in turn improve the plants' ability to absorb nitrate nitrogen. Additionally, all biochar amendments boosted anthocyanin production in leaf lettuce save for BB300 2\%. This result indicates that anthocyanin development is favored by biochar addition into the soil in accordance with several previous studies for example by Hilioti et al. [39].

The current study was conducted to elucidate the most suitable option of recycling brewer's spent grain through pyrolysis for optimized agricultural productivity. The experimental results clearly show that the biochar pyrolyzed at $500{ }^{\circ} \mathrm{C}$ is the most suited for the soil amendment role. Except the $\mathrm{BB}_{500}$ treatment which performed relatively well at both application rates even though the $\mathrm{BB}_{500}$ $5 \%$ produced the most outstanding resuts of the two, all the remaining amendments produced better growth results when applied at a rate of $2 \%$. Additionally, application of pristine BSG to the soil should be avoided if maximum agronomic benefits are to be realized. In summary, therefore, biochar production from brewer's spent grain looks a sound way of recycling the waste but since this study only looked at the effects on soil chemical properties and agronomic performance of the leaf lettuce 
grown, more studies are required to unlock the unknown merits of biochar derived from brewer's spent grain.

\section{Acknowledgements}

This research study was conducted with support from a research grant awarded by the Cooperative Research Program for Agriculture Science \& Technology Development of Rural Development Administration, Republic of Korea (Project No. PJ01425302).

\section{Authors' contributions}

J-HY conceived and designed the experiment, collected samples, performed part of the laboratory analysis and drafted the manuscript. DL edited the manuscript to improve the English language quality. J-HL and S-YP performed the laboratory analyses of plant samples while J-WY and J-YA carried out the soil laboratory analyses. Y-UY and T-KO supervised the study and provided technical guidance. All authors read and approved the final manuscript.

\section{Data availability}

The data to support the conclusions made in the study are included in the manuscript while small amounts of the produced biochars can be provided to anyone upon request.

\section{Competing interests}

The authors declare that they have no conflict of interest.

Received: 17 October 2020 Accepted: 2 December 2020

Published online: 20 January 2021

\section{References}

1. Cho YG, Kang HS, Jeon EC (2016) The effects of reactive nitrogen ( $\mathrm{Nr}$ ) compounds on the acidification in soil and water environment ecosystems and the mitigation strategy. Korean Soc Limnol KJEE 49(1):1-10 (in Korean)

2. Lee MH, Choi SI, Lee JY, Lee KG, Park JW (2011) Soil and Groundwater Environment. Donghwa Publishing Co., Paju-si (in Korean)

3. Sohi SP (2012) Carbon storage with benefits. Science 338(6110):1034-1035

4. Woo SH (2013) Biochar for soil carbon sequestration. Clean Technol 19(3):201-211 (in Korean)

5. Oh TK, Lee JH, Kim SH, Lee CH (2017) Effect of biochar application on growth of Chinese cabbage (Brassica chinensis). Korean J Agric Sci 44(3):359-365. https://doi.org/10.7744/kjoas.20170039 (in Korean)

6. Cao X, Harris W (2010) Properties of dairy-manure-derived biochar pertinent to its potential use in remediation. Bioresour Technol 101(14):5222-5228

7. Beesley L, Moreno-Jiménez E, Gomez-Eyles JL, Harris E, Robinson B, Sizmur T (2011) A review of biochars' potential role in the remediation, revegetation and restoration of contaminated soils. Environ Pollut 159(12):3269-3282

8. Oh TK, Choi B, Shinogi Y, Chikushi J (2012) Effect of pH conditions on actual and apparent fluoride adsorption by biochar in aqueous phase. Water Air Soil Pollut 223(7):3729-3738

9. Woolf D, Amonette JE, Street-Perrott FA, Lehmann J, Joseph S (2010) Sustainable biochar to mitigate global climate change. Nat Commun 1(5):1-9

10. Yoo GY, Son YG, Lee SH, Yoo Y, Lee SH (2013) Greenhouse gas emissions from soils amended with biochar. Korean J Environ Biol 31(4):471-477 (in Korean)

11. Choi SY, Kim SC, Shin JD (2015) Adsorption characteristics and kinetic models of ammonium nitrogen using biochar from rice hull in sandy loam soil. Korean J Soil Sci Fert 48(5):413-420 (in Korean)

12. Woo SH, Woo HC (2015) Estimation of carbon mitigation in South Korea by biochar system. KOSECC 2015(6):163-163 (in Korean)

13. Park JY (2016) Soil improvement and carbon isolation using biochar Korea Environmental Industry Technology Institute. Konetic Report 2016-148 (in Korean)
14. Jeong BG, Oh SH, Chun JY (2017) Nutritional and functional properties of water extracts from Achyranthes japonica Nakai-Rice Pilsner byproducts. J Korean Soc Food Sci Nutr 46(2):185-195 (in Korean)

15. Mussatto SI, Dragone G, Roberto IC (2006) Brewers'spent grain: generation, characteristics and potential applications. J Cereal Sci 43(1):1-14

16. Lee JY, Kim CH, Chio JS, Kim BH, Lim GB, Kim DM (2012) Development of new powdered additive and its application for improving the paperboard bulk and reducing drying energy (I) - analysis of chemical and physical properties of brewers grain. J Korea TAPPI 44(2):58-66 (in Korean)

17. Kim YS, Lee SH, Lee WK (2013) Development of impregnated adsorbent for mercury removal using sewage sludge. J Korea Soc Waste Manag 30(8):793-797 (in Korean)

18. Park WS, Kim HJ, Chung HJ, Chun MS, Kim ST, Seo SY, Lim SH, Jeong YH, Chun JW, An SK, Ahn MJ (2015) Changes in carotenoid and anthocyanin contents, as well as antioxidant activity during storage of lettuce. J Korean Soc Food Sci Nutr 44(9):1325-1332 (in Korean)

19. Korean Seed Association (KOSA) (2018) (in Korean) http://www.kosas eed.or.kr/

20. Mulabagal V, Ngouajio M, Nair A, Zhang Y, Gottumukkala AL, Nair MG (2010) In vitro evaluation of red and green lettuce (Lactucasativa) for functional food properties. Food Chem 118(2):300-306

21. Jung SH (2014) Effects of biochar derived from agricultural and forest residue on carbon sequestration and soil quality. Master dissertation, Kangwon National University. Chuncheon, Korea

22. Rural Development Administration (RDA) (2017) Salt stress and reduction countermeasure. pp 3-6 (in Korean)

23. National Institute of Agricultural Science and Technology (NIAST) (2000) Methods of soil and plant analysis. Rural Development Administration, pp 103-146 (in Korean)

24. Rural Development Administration (RDA) (2012) Standards for research and analysis of agricultural science and technology. pp 533-537 (in Korean)

25. Lim JE, Kim HW, Jeong SH, Lee SS, Yang JE, Kim KH (2014) Characterization of burcucumber biochar and its potential as an adsorbent for veterinary antibiotics in water. J Appl Biol Chem 57:65-72. https://doi.org/10.3839/ jabc.2014.011 (in Korean)

26. Ahmad M, Lee SS, Dou X, Mohan D, Sung JK, Yang JE, Ok YS (2012) Effects of pyrolysis temperature on soybean stover- and peanut shell-derived biochar properties and TCE adsorption in water. Bioresour Technol 118:536-544. https://doi.org/10.1016/j.biortech.2012.05.042

27. Shinogi Y, Kanri Y (2003) Pyrolysis of plant, animal and human waste: physical and chemical characterization of the pyrolytic products. Bioresour Technol 90:241-247. https://doi.org/10.1016/S0960-8524(03)00147 $-0$

28. Oh TK, Shinogi Y, Lee SJ, Choi B (2013) Utilization of biochar impregnated with anaerobically digested slurry as slow-release fertilizer. J Plant Nutr Soil Sci 177(1):97-103

29. Cantrell KB, Hunt PG, Uchimiya M, Novak JM, Ro KS (2012) Impact of pyrolysis temperature and manure source on physicochemical characteristics of biochar. Bioresour Technol 107:419-428. https://doi. org/10.1016/j.biortech.2011.11.084

30. Lim JE, Lee SS, Ok YS (2015) Efficiency of poultry manure biochar for stabilization of metals in contaminated soil. J Appl Biol Chem 58(1):39-50 (in Korean)

31. Yang JE, Park CJ, Yong SH, Kim JJ (1999) Changes in characteristics of bark and piggery manure by-product fertilizers during the composting. Korean J Environ Agric 18(4):372-377 (in Korean)

32. Kang K, Hong SG (2018) Characteristics of soil nutrients by the application of rice straw ash. J Korean Soc Agric Eng 60(5):105-113 (in Korean)

33. Lee JH, Seong CJ, Kang SS, Lee HC, Kim SH, Lim JS, Kim JH, Yoo JH, Park $\mathrm{JH}$, Oh TK (2018) Effect of different types of biochar on the growth of Chinese cabbage (Brassica chinensis). Korean J Agric Sci 45(2):197-203. https://doi.org/10.7744/kjoas.20180033 (in Korean)

34. Lee JH, Luyima D, Lee JY, Kim SJ, Oh TK (2019) Effects of two biocharbased organic amendments on soil chemical properties and productivity of selected vegetables. J Fac Agric Kyushu Univ 64(1):39-46

35. Jeffery $S$, Verheijen FGA, van der Velde M, Bastos AC (2011) A quantitative review of the effects of biochar application to soils on crop productivity using meta-analysis. Agric Ecosyst Environ 144(1):175-187 
36. Singh B, Singh BP, Cowie AL (2010) Characterisation and evaluation of biochars for their application as a soil amendment. Aust J Soil Res 48(7):516

37. Luyima D, Lee JH, Yoo JH, Kim SH, Shinogi Y, Sung JK, Oh TK (2019) Post-pyrolysis nutrient enhancement of wood biochar with compost and uncharred wastes- influence on soil chemical properties and crop productivity. J Fac Agric Kyushu Univ 64(2):199-204

38. Chan KY, Van Zwieten L, Meszaros I, Downie A, Joseph S (2007) Agronomic values of green waste biochar as a soil amendment. Aust J Soil Res 45(8):629
39. Hilioti Z, Michailof CM, Valasiadis D, Iliopoulou EF, Koidou V, Lappas AA (2017) Characterization of castor plant-derived biochars and their effects as soil amendments on seedlings. Biomass Bioenergy 105:96-106. https ://doi.org/10.1016/j.biombioe.2017.06.022

\section{Publisher's Note}

Springer Nature remains neutral with regard to jurisdictional claims in published maps and institutional affiliations.

\section{Submit your manuscript to a SpringerOpen ${ }^{\circ}$ journal and benefit from:}

- Convenient online submission

- Rigorous peer review

- Open access: articles freely available online

- High visibility within the field

- Retaining the copyright to your article

Submit your next manuscript at $\boldsymbol{\sim}$ springeropen.com 